\title{
Potret Kebijakan Inovasi Pelayanan Publik di Indonesia Tahun 2020
}

\author{
Suranto Suranto ${ }^{\circledR}$, Awang Darumurti ${ }^{1}$, Dwian Hartomi Akta Padma Eldo ${ }^{2}$, Akhmad Habibullah ${ }^{2}$ \\ ${ }^{1}$ Universitas Muhammadiyah Yogyakarta, Jalan Brawijaya Tamantirta, Kasihan, Bantul Yogyakarta. 55183, Indonesia. \\ ${ }^{2}$ Universitas Pancasakti Tegal, Jalan Halmahera Km. 1, Kota Tegal, Jawa Tengah, 53121, Indonesia.
}

\begin{tabular}{|c|c|}
\hline ARTICLE INFORMATION & $\mathrm{A} B \mathrm{~S} \mathrm{~T} \mathrm{R}$ A $\mathrm{C}$ \\
\hline $\begin{array}{l}\text { Received: September 06, } 2021 \\
\text { Revised: October 01, } 2021 \\
\text { Accepted: October 22, } 2021 \\
\text { Available online: October 28, } 2021\end{array}$ & \multirow{6}{*}{$\begin{array}{l}\text { Public service innovation is the primary key to good governance development launched in most countries in the } \\
\text { world, including Indonesia. There have been many innovative programs carried out by several Ministries, } \\
\text { Institutions, and Local Governments in practice. Still, there is no comprehensive portrait related to the } \\
\text { tradition of public service innovation. The study aims to obtain a complete description of the public service } \\
\text { innovation practices in } 2020 \text { using indicators of innovators, types of innovation, goals and achievements of } \\
\text { innovation, policy sector and geographical aspects. This descriptive-explorative research type applies an } \\
\text { archival method that focuses on secondary data usage, and the results are then analyzed using both Nvivo } 12 \\
\text { and SPSS. The result shows that: (1) Innovators are dominated by local governments because the scope of } \\
\text { service issues is more varied and specific. (2) The type of policy innovation that is oriented to the process aspect } \\
\text { dominates the proposed proposal because of the ease and implementation factor. (3) Most innovation outcomes } \\
\text { are in problem-solving, which shows the orientation to problem-solving that is more practical and real impact. } \\
\text { (4) The health sector is getting more attention in policy innovation because of the trend of actual needs in the } \\
\text { field, making it the primary sector. (5) The institution participants in Java island are much higher than outside } \\
\text { Java, showing the imbalance in the quality of human resources }\end{array}$} \\
\hline KEYWORDS & \\
\hline $\begin{array}{l}\text { Policy Innovation, Public Services, Bureaucratic } \\
\text { Reform }\end{array}$ & \\
\hline CORRESPONDENCE & \\
\hline Name: Suranto & \\
\hline E-mail: suranto@umy.ac.id & \\
\hline
\end{tabular}

\section{PENDAHULUAN}

Kebijakan Inovasi layanan publik telah berkembang pesat di banyak negara-negara Barat (Borins, 2008) yang kemudian menyebar ke negara-negara berkembang termasuk Indonesia. Dengan menerapkan inovasi, organisasi public akan dapat meningkatkan kualitas layanan public (Damanpour \& Schneider, 2009) dan meningkatkan kinerja layanan (Walker, Jeanes, o Rowlands, 2002). Untuk mencapai efektivitas dan efisiensi, Sebagian besar pemerintah bergantung pada inovasi yang sukses mendayagunakan sumber daya dan teknologi (Mulgan e Albury, 2003).

Tingkat urgensi dan keutamaan inovasi kebijakan pada sektor publik telah mendorong sebagian besar Pemerintah di dunia menerapkan inovasi kebijakan menuju layanan publik yang prima. Demikian pula halnya dengan Pemerintah Indonesia juga committed untuk mengembangkan inovasi pelayanan publik melalui Peraturan Pemerintah Nomor 38 Tahun 2017 tentang Inovasi Daerah yang mengatur bagaimana organisasi baik Kementerian, Lembaga maupun Pemerintah Daerah melakukan inovasi daerah. Ruang lingkup kebijakan tersebut meliputi inovasi tata kelola pemerintahan dan penyelenggaraan pelayanan publik.

Selain intervensi melalui regulasi, kebijakan pemberian penghargaan dan kompetisi bagi organisasi publik merupakan salah satu alternatif untuk memacu inovasi di organisasi sektor publik. Jumlah skema penghargaan kompetitif pada layanan publik telah berkembang secara signifikan sebagai sarana untuk merayakan kinerja tinggi dan menyebarkan praktik yang baik (Jean e Downe, 2007).

Sejak 2003, Perserikatan Bangsa-Bangsa melalui Departemen Ekonomi dan Sosial telah meluncurkan The United Nations Public Service Awards (UNPSA) untuk mengapresiasi inovasi yang berhasil dilaksanakan oleh pemerintah dan organisasi publik di lima benua. Inisiatif ini juga diikuti oleh banyak negara termasuk Pemerintah Indonesia. Kementerian Pendayagunaan Aparatur Negara Republik Indonesia telah menyelenggarakan kompetisi inovasi pelayanan publik sejak tahun 2014 yang bertujuan untuk menjaring inovator sebagai perwakilan negara di UNPSA.

Kompetisi Nasional Indonesia untuk Inovasi Pelayanan Publik sempat mendapat respon yang antusias dari Kementerian, Lembaga dan Pemerintah Daerah, meski sempat merosot pada 2018. Adapun deskripsi trend-nya bisa dilihat pada gambar 1. berikut:

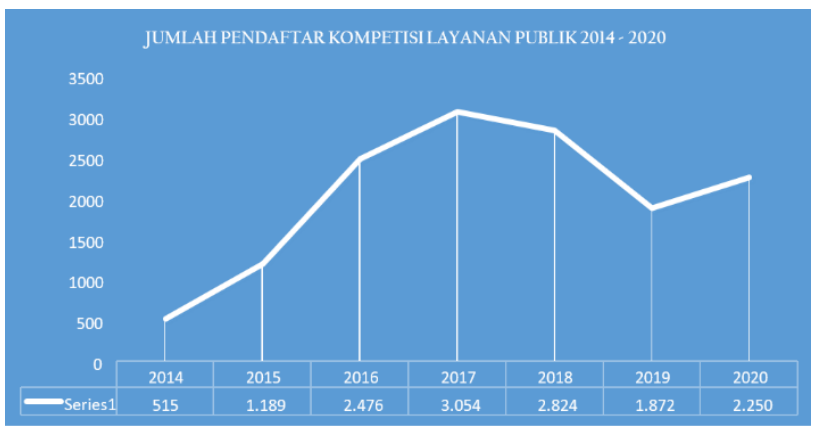

Gambar 1. Jumlah Pendaftar Kompetisi Layanan Publik KemenPAN RB Tahun 2014-2020

Sumber: KemenPan-RB (Data Diolah Peneliti)

Semua usulan program inovasi dievaluasi melalui penilaian berbasis online-desk oleh penguji independen yang menghasilkan 99 inovator teratas. Penilaian terakhir adalah 9 teratas pada tahun 2014, 25 teratas pada tahun 2015 dan 35 teratas pada tahun kompetisi 2016, dan selanjutnya 45 teratas sampai tahun 2020. Hal ini menunjukkan semakin banyaknya instansi 
pemerintah, serta organisasi publik di Indonesia yang mau berinovasi dalam memberikan pelayanan publik.

Namun, upaya yang dilakukan untuk menyelidiki inisiatif inovasi pelayanan publik secara komprehensif masih terbatas. Dengan demikian, sedikit penjelasan yang diketahui tentang inovasi pelayanan publik di Indonesia, terutama yang telah diakui dan dinilai oleh Kementerian Pendayagunaan Aparatur Negara. Di bidang akademik, penelitian tentang inovasi sektor publik sebagai salah satu mekanisme reformasi bukanlah hal yang baru dan telah banyak dipelajari dalam beasiswa administrasi publik. Anehnya, sebagian besar publikasi bertema inovasi publik relatif baru sejak diterbitkan antara 2009-2014 dan sangat terfokus pada perspektif AmerikaAngloSaxon (De Vries, Bekkers, \& Tummers, 2016). Selain itu, studi dalam perspektif regional dan internasional cenderung menekankan pada metrik, indeks dan instrumen pengukuran untuk inovasi sektor publik dan kebanyakan berlangsung dalam konteks barat (Bloch $\approx$ Bugge, 2013).

Sedangkan dalam konteks Indonesia, penelitian tentang inovasi publik lebih banyak menekankan pada inovasi teknologi dan pendekatan studi kasus (Jati, 2011, Anggadwita \& Dhewanto, 2013; Lembaga Administrasi Negara, 2014, Fahlevi, 2014; Santoso, 2015; Sutanto, 2017). Kajian yang dipublikasikan ini belum mampu menangkap gambaran besar inovasi layanan publik Indonesia. Dengan kata lain, tidak ada satupun studi di atas yang menawarkan analisis komprehensif tentang inovasi pelayanan publik yang dilaksanakan oleh organisasi publik di Indonesia.

Mengingat kesenjangan penelitian, terutama konteks di mana inovasi pelayanan publik telah terjadi, ada dorongan untuk mempelajari inovasi pelayanan publik dalam sistem administrasi non barat. Analisis komprehensif di satu negara tertentu dari waktu ke waktu akan bermanfaat, karena menawarkan perspektif alternatif tentang masalah ini. Penelitian ini bertujuan untuk melakukan analisis komprehensif terhadap karakteristik inovasi pelayanan publik Indonesia yang diambil dari Kompetisi Inovasi Pelayanan Publik Indonesia 2018-2020. Secara pragmatis, studi ini bertujuan untuk menangkap lanskap inovasi layanan publik Indonesia selama periode tersebut. Memahami lanskap inovasi layanan publik dapat meningkatkan pemahaman kita tentang bagaimana inovasi telah diterapkan oleh berbagai organisasi publik di Indonesia. Dengan demikian, pemerintah dapat menggunakan hasil penelitian ini sebagai fakta dasar dalam merancang kebijakan inovasi pelayanan publik. Secara teoritis, studi ini akan memberikan gambaran yang komprehensif tentang inovasi pelayanan publik dalam konteks Indonesia sebagai salah satu contoh spesifik sistem administrasi publik negara sedang berkembang.

\section{Inovasi Sektor Publik: Sejarah Perkembangan}

Untuk memahami inovasi pelayanan publik, perlu ditelusuri pengertian inovasi untuk mendapatkan gambaran yang komprehensif tentang terminologi dan penggunaannya dalam konteks sektor publik. Konsep "inovasi" diinisiasi oleh Schumpeter pada akhir 1920 (Hansen \& Wakonen, 1997) untuk menunjuk aplikasi komersial dari teknologi baru, material baru, dan metode baru dalam kemajuan pembangunan ekonomi dan industrialisasi. Dengan demikian, dibandingkan dengan sektor publik, studi inovasi di bidang bisnis dan swasta lebih mapan dalam bidang studi (Fragerberg, Mowery, \& Nelson, 2005). Yang membedakan antara inovasi publik dan swasta adalah kekuatan pendorong dalam implementasinya. Yang pertama menekankan pada barang publik dan nilai-nilai publik, yang berarti lembaga pemerintah mendorong program inovasi untuk mencapai perbaikan yang luas dalam tata kelola dan kinerja layanan, termasuk efisiensi dan upaya untuk meningkatkan nilai publik. Sedangkan yang terakhir terobsesi oleh keunggulan kompetitif dan motif yang berorientasi pada profit (Urbancova, 2013).

Dalam kajian administrasi publik, studi tentang inovasi pertama kali muncul pada tahun 1960-an. Artikel berjudul Inovasi dalam Lembaga Birokrasi diterbitkan dalam Public Administration Review (Diamant, 1967). Dua tahun kemudian, sebuah artikel berjudul Reformasi Administrasi (Caiden, 1969) diterbitkan dengan alasan bahwa inovasi di sektor publik adalah bagian dari reformasi administrasi. Publikasi ini dianggap sebagai titik awal studi inovasi di sektor publik. Perkembangan penelitian inovasi sektor publik menjanjikan masa depan yang cerah. Baru-baru ini, minat untuk mengungkap properti inovasi yang tidak diketahui di sektor publik telah berkembang pesat.

Sebuah studi komprehensif tentang inovasi sektor publik (De Vries, Bekkers, \& Tummers, 2016) menawarkan tinjauan literatur yang luas tentang inovasi sektor publik. Tinjauan sistematis literatur mereka berdasarkan penelitian empiris dari publikasi tertulis bahasa Inggris dalam jurnal peer reviewed internasional yang berlangsung dari Januari 1990 hingga Maret 2014 memberikan gambaran yang lebih jelas tentang bagaimana inovasi berkembang di sektor publik. Sebagai tinjauan sistematis, inovasi pelayanan publik yang dilakukan di Indonesia 27 secara transparan dari jurnal akademis yang terkenal dan terkenal, karya mereka menawarkan analisis yang kuat dan mewakili tubuh literatur dalam penelitian inovasi sektor publik.

Berdasarkan studi tersebut, beberapa temuan penting telah diidentifikasi. Pertama, sebagian besar studi inovasi sektor publik bersifat kualitatif dengan pendekatan studi kasus yang digunakan sebagai desain penelitian, sedangkan studi kuantitatif dan metode campuran lebih kecil jumlahnya. Proporsi terbesar dari literatur yang tersedia berasal dari konteks barat. Kedua, porsi terbesar kajian inovasi dilakukan di tingkat pemerintah daerah, diikuti oleh pemerintah pusat dan organisasi publik dan nirlaba lainnya. Ketiga, banyak studi inovasi menaruh perhatian utama mereka pada berbagai bidang kebijakan yang diikuti oleh sektor perawatan kesehatan, namun hanya sedikit studi yang meneliti sub sektor kesejahteraan atau pendidikan. Akhirnya, anteseden organisasi memainkan peran terbesar dalam memungkinkan semua jenis inovasi sementara inovasi tata kelola sering dihubungkan dengan anteseden lingkungan, termasuk sumber daya dari mitra swasta. Hasil utama ini telah menginformasikan keadaan penelitian inovasi sektor publik dan panggilan untuk analisis yang lebih komprehensif terutama di negara berkembang.

\section{Definisi Inovasi Pada Sektor Publik}

Inovasi adalah konsep yang kompleks dan telah didefinisikan dengan berbagai cara. Definisi tersebut sangat bergantung pada konteks-nya, latar belakang disiplin ilmu dan aliran penelitiannya. Sifat lintas disiplin studi inovasi dan berbagai metodologi-nya juga berkontribusi pada makna yang tersebar. Sederhananya, inovasi dianggap sebagai "melakukan 
sesuatu secara berbeda" (Hansen \& Wakonen, 1997). Di sektor publik, secara khusus, Mulgan dan Albury (2003) mendefinisikan inovasi publik yang sukses adalah penciptaan dan pelaksanaan proses, produk, layanan, dan metode baru penyampaian dalam memberikan layanan publik. Hal Ini kemudian menghasilkan peningkatan yang signifikan dalam hasil, efisiensi dan efektivitas atau kualitas layanan publik. Definisi ini menggarisbawahi sifat domain publik dan menekankan pada nilai-nilai administratif.

Pakar lain menyoroti pentingnya kreativitas, yang berarti menciptakan cara baru dalam melakukan sesuatu. Hal ini sejalan dengan akar ilmu ekonomi dan manajemen yang menganjurkan inovasi sebagai kebaruan dalam tindakan. Para sarjana dengan perspektif kebaruan percaya gema inovasi ditekankan dalam konsep kebaruan. (Bhatti, Olsen, \& Pederson, 2011) menggarisbawahi bahwa kebaruan sebagai karakteristik inti dari inovasi. Hasilnya tercermin dalam produk baru, metode produksi, pasar, sumber pasokan, dan struktur organisasi. Perspektif ini dapat dikelompokkan menjadi definisi berbasis kebaruan.

Sementara itu, Cluster lain menangani proses adopsi. Perspektif ini memandang inovasi sebagai tindakan mengadopsi. Ini tidak hanya untuk penemuan atau sesuatu yang muncul untuk pertama kalinya tetapi juga penggunaan ide yang ada dalam pengaturan dan konteks baru. (Rogers, 2003) mendefinisikan inovasi sebagai "ide, praktik, atau objek yang dianggap baru oleh individu atau unit adopsi lain". (Rogers, Medina, \& Wiley, 2005) menekankan pada gagasan inovasi sebagai "difusi." Argumen ini sejalan dengan (Hartley, 2005) yang berpendapat bahwa inovasi dapat mencakup penemuan kembali atau adopsi ke konteks, lokasi atau kerangka waktu lain. Inovasi sebagai proses adopsi sangat didukung oleh transfer kebijakan dan studi difusi kebijakan.

\section{Tujuan dan Capaian Inovasi}

Pengesahan inovasi di sektor publik ditujukan untuk memenuhi berbagai kebutuhan masyarakat dan mengatasi masalah publik. Dengan demikian, inovasi yang dipraktikkan oleh organisasi publik harus memiliki pernyataan tujuan, yang memandu pelaksana selama proses inovasi. Selain pernyataan tujuan di awal, hasil dari inovasi harus dinilai di akhir siklus inovasi. Dalam logika ini, pernyataan tujuan di awal dan dampak inovasi sebagai hasil program sangat penting dalam mengevaluasi inovasi sektor publik. Menggambar dari penelitian tentang inovasi sektor publik selama dua dekade, De Vries et al. (2016) telah mengidentifikasi bahwa setidaknya enam tujuan dan hasil diharapkan. Inovasi di sektor publik ditujukan untuk meningkatkan efektifitas, efisiensi, mengatasi masalah kemasyarakatan, meningkatkan kepuasan warga, melibatkan warga dan melibatkan mitra swasta untuk berkontribusi dalam pelayanan publik.

\section{Aspek Kebijakan dan Geografis}

Poin penting lainnya dalam memahami inovasi sektor publik adalah mempertimbangkan wilayah kebijakan di mana inovasi terjadi dan di mana inovasi terjadi. Kedua poin ini penting karena Pertama, urusan publik adalah masalah yang sangat luas yang terwujud di hampir setiap aspek manusia. Mengetahui aspek kehidupan dan intervensi pemerintah seperti apa yang dilakukan untuk menyelesaikan masalah akan bermanfaat untuk mengidentifikasi kesenjangan sektor kebijakan atau bidang kebijakan. Pembuat kebijakan dapat mengidentifikasi kekurangan inovasi atau bahkan tumpukan inovasi dalam memberikan layanan publik. Kedua, Indonesia sebagai negara kepulauan yang memiliki lebih dari 17.000 pulau dan 497 pemerintah daerah, dianggap sebagai sistem pemerintahan bertingkat yang kompleks. Pemetaan sebaran inovasi antar daerah dalam perspektif geografis dapat membantu pemerintah Indonesia mengetahui disparitas antardaerah. Dalam perspektif nusantara, analisis geografis ditujukan untuk Jawa dan Luar Jawa.

\section{METODE}

Jenis penelitian adalah kualitatif dengan pendekatan deskriptif-eksploratif, sedangkan metode penelitian yang digunakan adalah metode kearsipan yang berfokus pada penggunan secondary data, yang berupa data yang berasal dari literatur dan sumber-sumber yang terkait penelitian seperti buku, artikel jurnal dan pemberitaan dari media, yang selanjutnya hasil data tersebut dianalisis dengan menggunakan NVIVO 12+ dan SPSS. Penelitian ini menggunakan fitur Word frequency dengan analisis TreeMap, Analisis Treemap digunakan untuk melihat implementasi dari class interface yang mengurutkan data collection berdasarkan dari kata kunci yang ada dalam penelitian. Analisis Treemap juga bertujuan untuk memvisualisasikan data temuan tentang Inovasi pelayanan publik yang ada pada tahun 2020, sehingga dapat diketahui perkembangan inovasi yang ada

\section{HASIL DAN PEMBAHASAN}

Program Keluarga Harapan adalah program penanggulangan kemiskinan dan kedudukan $\mathrm{PKH}$ merupakan bagian dari program-program penanggulangan kemiskinan lainnya. Program Keluarga Harapan memberikan bantuan tunai kepada Rumah Tangga Sangat Miskin (RTSM), jika mereka memenuhi persyaratan yang terkait dengan upaya peningkatan kualitas hidup dalam bidang kesehatan dan pendidikan (Utomo, 2012).

Kementerian Pendayagunaan Aparatur Negara dan Reformasi Birokrasi Republik Indonesia (Kemenpan RB) Setiap tahun menganugrahkan penghargaan kepada 99 instansi pemerintahan terpilih dengan kategori melakukan inovasi di bidang pelayanan publik. Adapun syarat utama yang harus dipenuhi dalam kompetisi ini adalah inovasi sejalan dengan tema per tahunnya, memenuhi seluruh kriteria inovasi, serta memiliki relevansi dengan salah satu kategori inovasi dan kompetisi. Persyaratan lainnya adalah inovasi telah diimplementasikan dalam satu tahun terakhir yang dihitung mundur dari waktu yang telah ditentukan serta melampirkan bukti yang valid hasil inovasi yang dilaksanakan.

Kompetisi Inovasi Pelayanan Publik (KIPP) yang dimulai sejak 2013 ini melibatkan seluruh instansi pusat dan daerah, Badan Usaha Milik Negara (BUMN), serta Badan Usaha Milik Daerah (BUMD) telah memberikan dampak positif bagi pemerintah, namun sayangnya gairah untuk berinovasi di instansi pemerintahan Mengalami penurunan di tahun 2019 dan tahun 2020, jika dibandingkan pada tahun sebelumnya

Melalui data yang diambil menggunakan google trend dengan rentang waktu dari 2018-2020 dengan kata kunci "Pelayanan Publik" data menunjukkan isu-isu pelayanan publik di 
mengalami kenaikan dan penurunan trend setiap tahunan, seperti pada grafik 1 . berikut:

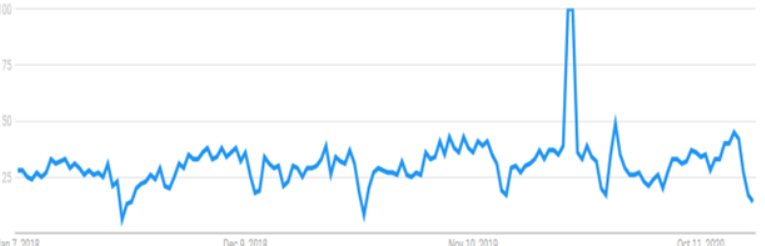

Grafik. 1 Trend Pelayanan Publik di Indonesia Tahun 2018-2020 Sumber: https://trends.google.co.id

Selain trend pelayanan, melalui google trend, penelitian ini juga mengungkap trend Inovasi yang dilakukan oleh pemerintahan di Indonesia, namun memang tingkat inovasi yang ada tidak sebanding dengan trend pelayanan publik yang sudah ada. Hal ini disebabkan belum semua pelayanan yang ada memiliki inovasi, karena sulitnya menemukan kebaruan dan pemenuhan syarat inovasi yang cukup rumit.

Adapun data trend inovasi dan pelayanan publik yang tumbuh sejak tahun 2018 hingga tahun 2020 di Indonesia berdasarkan google trend adalah sebagai berikut pada grafik 2 :

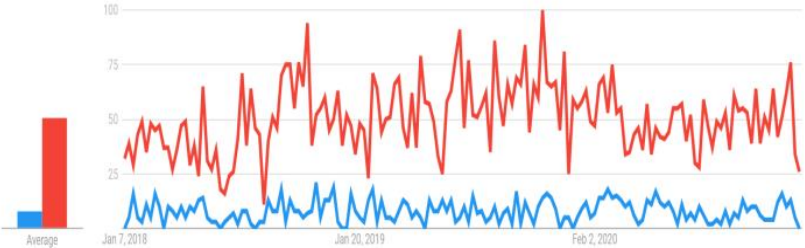

Grafik 2. Trend Pelayanan Publik dan Inovasi Pelayanan Publik di Indonesia Tahun 2018-2020

Sumber: https://trends.google.co.id

Grafik trend warna merah adalah trend isu pelayanan publik yang muncul selama periode 2018-2020 sedangkan grafik yang berwarna biru adalah inovasi yang ada selama masa yang sama yaitu periode 2018-2020. Hal ini memperkuat argument sebelumnya yang menyatakan inovasi sulit dilakukan karena harus ada kebaruan dan juga harus memenuhi indikator inovasi itu sendiri seperti (1) nilai lebih (relative advantage), (2) kesesuaian dengan masalah (compatibility/contextuality); (3) daya jangkau (complexity); (4) kemudahan diamati (observability); (5) bisa dicoba (triability). (Mirnasari, 2019)

Konsep inovasi dan kebijakan publik adalah laksana dua sisi dari mata uang. Di satu sisi, inovasi memberikan pengetahuan dan pengalaman baru yang bermanfaat bagi pengembangan kebijakan publik seentara kebijakan publik menyediakan teori, pedoman dan metode yang akan memantapkan inovasi kebijakan. Upaya inovasi kebijakan berdimensi aspek "baru" dan "bermanfaat" sehingga diharapkan berdampak positif pada upaya membangun partisipasi masyarakat secara kontinyu. Inovasi diimplementasikan tidak hanya pada tahap evaluasi kebijakan, namun diterapkan sejak formulasi, implementasi dan evaluasi kebijakan publik. Inovasi kebijakan harus muncul dari sebuah sistem mapan dan efek dari public management knowledge yang dilembagakan organisasi, bukan karena faktor kepemimpinan atau krisis yang memaksa organisasi untuk ikut melakukan perubahan (Sururi, 2019)
Untuk melihat kata yang paling sering muncul saat kita membahas pelayanan public peneliti menggunakan aplikasi NVivo-12, dengan fitur word cloud. Fitur ini memungkinkan peneliti menampilkan data dari sinovik tahun 2020 berupa kumpulan kata yang paling sering muncul pada isu inovasi pelayanan pada tahun 2020 seperti gambar 2 berikut:

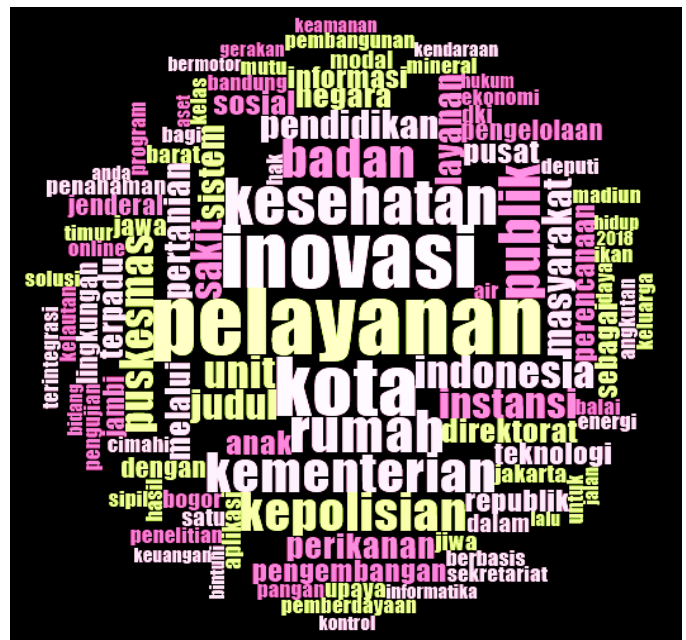

Gambar 2. Word cloud Inovasi Pelayanan Publik Tahun 2020 Sumber: diolah oleh peneliti menggunakan Nvivol2 plus.

Data di atas menunjukkan bahwa kata pelayanan dan inovasi adalah kata yang paling banyak muncul, yang diikuti kata-kata Kesehatan, Pendidikan, kementerian, kepolisian, pertanian, puskesmas dan lain sebagainya. Hal ini bermakna kata inovasi pelayanan sangat mendominasi dalam konteks pembahasan kebijakan publik di Indonesia pada tahun 2020. Selanjutnya juga ada kata-kata yang kecil namun memiliki makna yang cukup signifikan seperti integrasi layanan, teknologi layanan, unit dan instansi pelaku inovasi.

Selanjutnya untuk melihat potret inovasi pelayanan publik tahun 2020 ini akan didasarkan pada Top 99 Inovasi tahun 2020 yang direlease KemenPAN_RB, dengan menggunakan indikator inovator, tipe inovasi, tujuan dan outcomes, sektor kebijakan dan aspek geografis.

Dilihat dari aspek inovatornya, Pemerintah Daerah yang meliputi Pemerintah Provinsi, Pemerintah Kabupaten dan Pemerintah Kota menjadi pelaku inovasi yang dominan pada tahun 2020 yang mencapai 75\%. Sementara kontribusi peran Pemerintah Pusat yang dilakukan oleh Kementerian dan Lembaga hanya berkontribusi 25\%. Data selengkapnya dapat dilihat pada grafik 3 berikut:

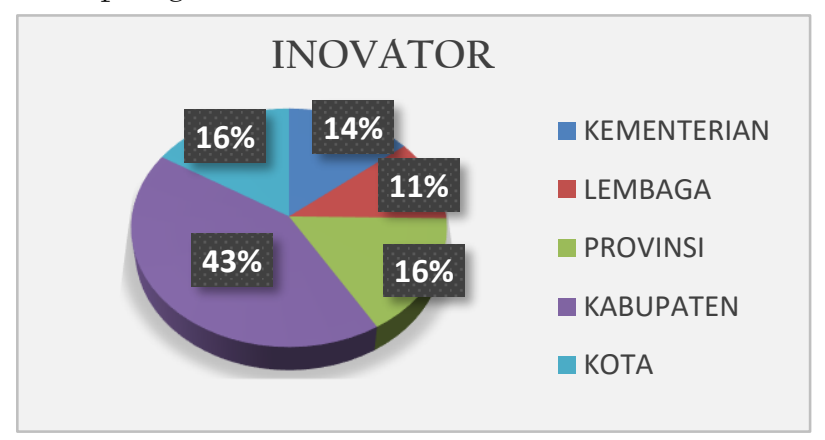

Grafik 3. Aspek Inovator 
Dari grafik tersebut terlihat bahwa Pemerintah Kabupaten yang mendominasi dengan kontribusi 43\%, disusul Pemerintah Kabupaten dan Kota masing-masing 16\%. Hal ini menunjukkan bahwa semakin rendah level inovatornya semakin banyak inovasinya. Hal ini di samping karena kuantitasnya yang besar, juga karena aspek keleluasaan dan keberagaman variasi layanan publik yang lebih operasional yang dapat diusulkan oleh Pemerintah Daerah.

Sementara itu ditinjau dari aspek tipe inovasi, tipe proses menjadi yang paling diminati yang mencapai 39\%, disusul produk layanan yang mencapai $36 \%$, dan tipe tata kelola yang hanya 25\%. Berikut disajikan pada grafik 4. Tentang Tipe Inovasi:

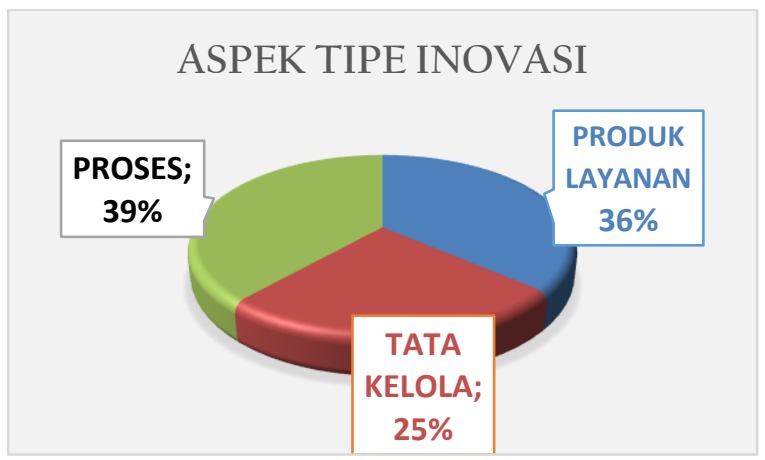

Grafik 4. Aspek Tipe Inovasi

Adapun yang dimaksud dengan tipe proses ini adalah bagaimana upaya pemerintah berupaya memotong garis birokrasi yang selama ini menjadi banyak keluhan masyarakat. Sedangkan produk layanan adalah terkait agar kemudahan akses pelayanan publik yang ada. Sementara tipe tata kelola terkait dengan manajemen pengelolaan layanan. Tingginya tipe proses dan produk layanan mencerminkan bahwa inovator cenderung fokus pada upaya efisiensi layanan yangmerupakan cerminan dari tuntutan masyarakat yang menghendaki pelayanan publik yang mudah diakses dan tidak berbelit-belit.

Sedangkan dilihat dari aspek tujuan dan outcomes, mayoritas usulan inovasi kebijakan pelayanan publik pada 2020 adalah terkait upaya pemecahan masalah (problem solving) yang mencapai 34\% disusul kepuasan publik sebesar 27\%. Data selengkapnya dapat dilihat pada Grafik 5 berikut:

\section{TUJUAN DAN OUTCOMES}

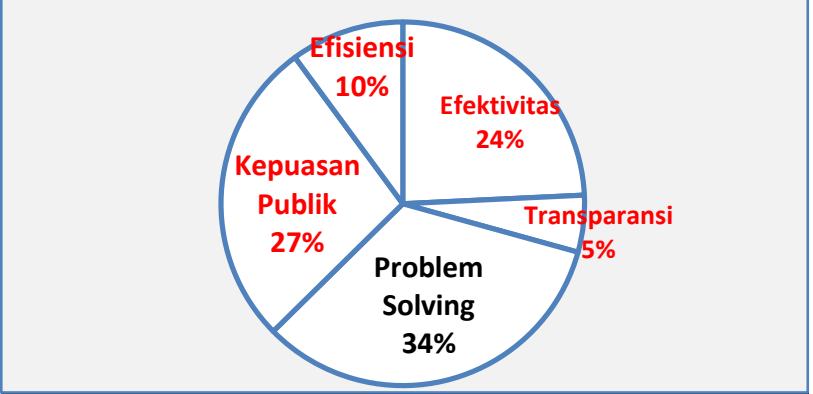

Grafik 5. Aspek Tujuan dan Outcome

Data tersebut menunjukkan bahwa inovator cenderung berorientasi pada hasil yang langsung terlihat dan berdampak pada teratasi isu-isu guna meningkatkan kepuasan publik, dibandingkan dengan aspek proses yang terdiri dari efisiens, efektivitas dan transparansi.
Selanjutnya, dilihat dari sektor kebijakan, Inovasi Pelayanan publik yang dilakukan oleh pemerintah pada tahun 2020 terbagi menjadi 5 aspek besar, yaitu Kesehatan, Pendidikan, ASN, Perijinan dan Pajak. Adapun distribusinya dapat dilihat pada Grafik 6 berikut:

\section{SEKTOR KEBIJAKAN}

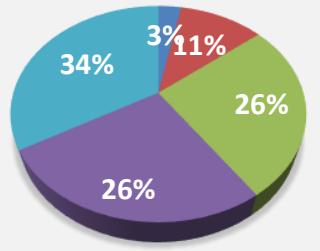

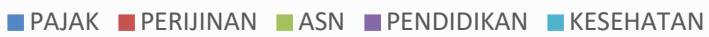

Grafik 6. Aspek Sektor Kebijakan

Dari grafik 6 terlihat bahwa sektor kesehatan menempati posisi teratas yang mencapai $34 \%$, disusul sektor pendidikan dan ASN sebesar 26\%. Sektor kesehatan sangat dominan dalam inovasi pada tahun 2020, karena menjadi pelayanan dasar yang sangat dibutuhkan masyarakat. Namun, uniknya tingginya Inovasi Kesehatan yang dilakukan oleh Pemerintah ternyata tidak berbanding lurus dengan kondisi pandemik yang ada. Masyarakat berharap pemerintah mampu memberikan Inovasi perihal penanganan Covid 19 ataupun pencegahan penularan yang inovatif, namun berdasarkan data hasil yang sudah tersaji hanya ada satu Inovasi terkait penanganan Covid 19.. Hal ini menunjukkan bahwa baik Pemerintah Pusat apalagi Pemerintah Daerah masih belum siap dan belum memiliki ide yang luas perihal inovasi yang dilakukan untuk membantu masyarakat yang terkendala dalam kondisi pandemi.

Akhirnya ditnijau dari aspek geografis, trend perkembangan Inovasi Pelayanan public lebih banyak dilakukan oleh Pemerintah yang ada di Pulau Jawa yang mencapai 64\% (lihat Grafik 7). Hal ini terjadi karena lokasi Pemerintah Pusat yang terdiri atas Kementerian dan Lembaga Negara berada di wilayah Administrasi DKI Jakarta, yang ada provinsi tersebut berada di Pulau Jawa. Di samping itu, aspek pemerataan sumberdaya manusia serta fasilitas yang tidak berimbang antara Pulau Jawa dan Luar Pulau Jawa juga turut berkontribusi.

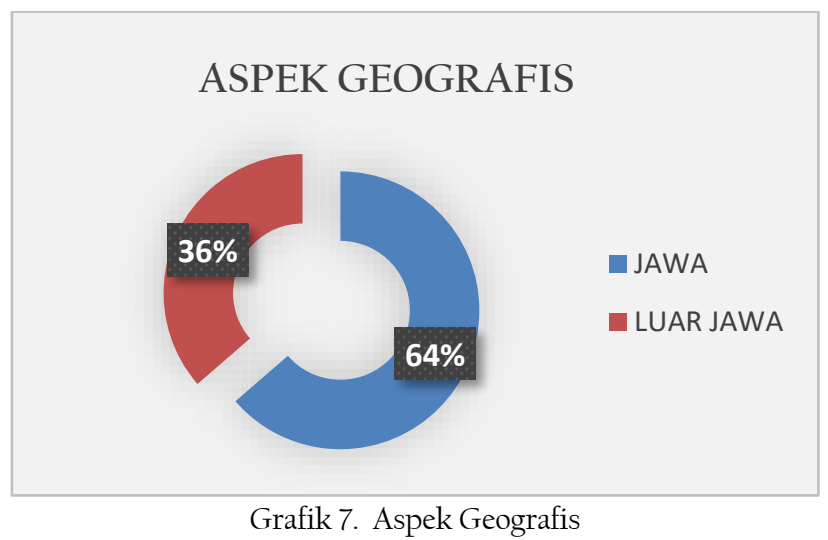

\section{KESIMPULAN}

Ada 5 kesimpulan yang dapat ditarik dari penelitian ini, yaitu: (1) Inovator didominasi oleh pemerintah daerah karena 
cakupan persoalan pelayanan lebih variatif dan spesifik daripada yang dimiliki Pemerintah Pusat. (2) Jenis inovasi kebijakan yang berorientasi pada aspek proses mendominasi usulan yang diajukan, karena faktor kemudahan dan implementasi. (3) Sebagian besar outcomes inovasi berupa pemecahan masalah, yang menunjukkan orientasi inovator pada pemecahan masalah yang lebih praktis dan berdampak nyata. (4) Sektor kesehatan merupakan sektor yang mendapat perhatian lebih dalam inovasi kebijakan karena adanya tren kebutuhan aktual di lapangan yang menjadikannya sebagai sektor utama. (5) Kepesertaan institusi di pulau Jawa jauh lebih tinggi daripada luar Jawa yang menunjukkan ketimpangan kualitas sumber daya manusia dan fasilitas di samping lokasi Pemerintah Pusat yang berada di Pulau Jawa.

\section{REFERENSI}

Anggadwita, G., \& Dhewanto, W. (2013). Service-InnovationIn-Public-Sector: A Case Study on PT. Keretaapi Indonesia. Journal of Social and Development Sciences, 308-315.

Bhatti, Y., Olsen, A. L., \& Pederson, L. H. (2011). Administrative Professionals and the Diffusion of Innovations: The Case of Citizen Service Centres. Journal Public Administration.

Bloch, C., \& Bugge, M. (2013). Public Sector Innovation-From Theory to Measurement. Structural Change and Economic Dynamics.

Borins, S. F. (2008). Innovations in Government. Washington DC: Brookings Institution.

Caiden, G. (1969). Administrative Reform. Chicago: Aldine Publisher.

Damanpour, F., \& Schneider, M. (2009). Characteristics of Innovation and Innovation Adoption in Public Organizations: Assessing yhe Role of Managers. Journal of Public Administration Research and Theory.

De Vries, H., Bekkers, V., \& Tummers, L. (2016). Innovation in the Public Sector: A Systematic Review and Future Research Agenda. Journal Public Administration.

Diamant, A. (1967). Innovation in Bureaucratic Institutions, Public Administration Review.

Eldo, D. H., \& Mutiarin, D. (2018). Analisis Best Practice Inovasi Pelayanan Publik (Studi pada Inovasi Pelayanan "Kumis Mbah Tejo" di Kecamatan Tegalrejo Kota Yogyakarta). Jurnal Manajemen Pelayanan Publik, 156-167.

Fahlevi, H. (2014). The Innovation of The Role of Accounting In Public Hospitals - Lesson Learned From Hospital Financing Reform In Indonesia And Germany. Jakarta: Https://Dopus.

UniSpeyer.De/Frontdoor/Deliver/Index/Docid/928/File/Her.

Fragerberg, J., Mowery, D., \& Nelson, R. (2005). The Oxford Handbook of Innovation. Oxford: UK: Oxford University Press.

Hansen, S., \& Wakonen, J. (1997). Innovation, A Winning Solution?. International Journal of Technology Management

Hartley, J. (2005). Innovation in Governance and Public Services: Past and Present. Journal Public Money and Management.

Jati, W. (2011). Inovasi Pelayanan Publik Setengah Hati: Studi Pelayanan Publik SAMSAT Kota Yogyakarta. Jurnal Ilmu Sosial Dan Ilmu Politik.
Jean, H., \& Downe, j. (2007). The Shining Lights? Public Service Awards as an Approach to Service Improvement. Journal Public Administration, 329-353.

Mulgan, G., \& Albury, D. (2003). Innovation in the Public Sector. London: UK Cabinet Office Strategy Unit.

Negara, L. A. (2014). Handbook Inovasi Administrasi Negara, Cetakan I. Jakarta: Pusat Intan-Dian-LAN.

Permatasari, E. Y. (2017). Inovasi pelayanan Publik di Kantor PT. Pos Kota Samarinda. Jurnal Administrasi Negara, 55335543.

Rogers, E. (2003). Diffusion of Innovations (5th Ed.). New York: NY: Free Press.

Rogers, E. M., Medina, U. E., \& Wiley, C. J. (2005). Complex Adaptive Systems and the Diffusion of Innovations. The Innovation Journal: The Public Sector Innovation Journal.

Santoso, M. I. (2015). Applying Interactive Planning on Public Service Leadership in the Directorate General of Immigration Indonesia. Procedia - Social and Behavioral Sciences, 400-410.

Sutanto, E. (2017). The Influence of Organizational Learning Capability and Organizational Creativity on Organizational Innovation of Universities in East Java, Indonesia. Asia Pacific Management Review.

Sutrisno, M. R., Zauhar, S., \& Said, A. (2013). Inovasi Peningkatan Kualitas Pelayanan Publik (Studi Pada Layanan Cetak Tiket Mandiri di Stasiun Besar Malang). Jurnal Administrasi Publik, 1814-1820.

Urbancova, H. (2013). Competitive Advantage Achievement through Innovation and Knowledge. Journal of Competitiveness.

Walker, R. M., Jeanes, E., \& Rowlands, R. (2002). Measuring Innovation - Applying the Literature-Based Innovation Output Indicator to Public Services. Journal Public Administration, 201-214. 